\title{
Overcoming Past Obstacles to Insurance in the New EU Countries
}

\author{
George M. von Furstenberg* (with Klaus Junker ${ }^{\dagger}$ ) \\ Department of Economics, Indiana University, Wylie Hall, Rm 105, Bloomington, IN 47405, U.S.A. \\ E-mail: vonfurst@indiana.edu
}

The newest EU member countries in Central and Eastern Europe went through a rapid transition from state to market direction of economic and financial affairs as well as of enterprises and social arrangements, including insurance. As incentive structures, property rights, rules of competition, and the assignment of liabilities changed, so did the risks associated with private operations and investments. This essay looks at some of the unexpected risk exposures and the means of coping with rapid change in incomplete financial markets largely through the eyes of a leading participant in the process.

The Geneva Papers (2005) 30, 296-311. doi:10.1057/palgrave.gpp.2510025

Keywords: privatization of insurance; incomplete financial markets; transition countries; bancassurance; income security; insurability

\section{Introduction}

As the first anniversary of European-Union (EU) membership for Central and East European (CEE) countries approaches, it is fitting to look back on how insurance services have developed in these countries as they overcame the legacy of socialist forms of organization. In doing so, I make extensive use of knowledge and experience generously shared with me during a long interview of Klaus Junker. Dr. Junker has been significantly involved with the development of the private insurance industry in CEE countries ever since 1989-1990, and he recalled for me some of the twists and turns along the way that hold interesting lessons. ${ }^{1}$

The first section portrays the difficult transformation of government-funded insurance monopoly arrangements under socialism to premium-financed, experience-

\footnotetext{
* J.H. Rudy Professor of Economics, Indiana University, Bloomington, IN 47405, U.S.A. Contact: vonfurst@indiana.edu. This paper, based on a March 2004 interview, was started while the author was a visiting research economist at the Deutsche Bundesbank, working on issues related to financial-market development in EU-accession countries, but responsibility for the project and its execution is his alone. All major issues addressed in this paper were first raised by or with Dr. Junker, and any additional sources and data used are clearly identified. A referee's comments proved very helpful in the revision process.

$\dagger$ Executive Vice President, Allianz. The views reported are not to be attributed to Allianz.

${ }^{1}$ As an academic eager to learn from gifted practitioners and to pass on their lessons, von Furstenberg (von Furstenberg and Ulan, 1998) has previously drawn on the work and testimony of seven of the world's best central bankers for providing insights on financial development and stabilization, always portraying one person's approach and reasoning at a time.
} 
rated contracts issued in markets for financial services that have since developed. Foreign participation in this process through local establishment and, to a smaller extent, cross-border provision of insurance services, and problems encountered, are analysed in the second section. One of these problems is the initial lack of investable markets in CEE countries and capital flight that is partly induced by the search for credible life insurance and long-term income-security. This discussion leads on to insurabilty under CEE and emerging-market conditions more generally in sections three and four. The difficulties of arranging marriages between banking and insurance in the CEE countries and elsewhere, and ways to overcome them, are the subject of the fifth section. The final section reflects on some of the experiences gained from insurance development in the CEE countries and what lessons they may hold for other transitions from public to private programmes.

\section{Transformation and rebirth of insurance in formerly socialist accession countries}

Before documenting the rapid catch-up of the development of contractual insurance in countries that have emerged from socialism, it is necessary to characterize their starting position, that is, the status quo ante.

There was very little contractual insurance under socialism since socialist governments collectively insure their citizens' health, survivor, and old age and disability pension needs - albeit often at a very low level of benefits and without the security of contract. Contractual insurance, which may be offered by and to public or private parties, differs from non-contractual or socialized insurance provision, in which market and choice elements are lacking. Because, under socialism, insurance tends to be financed from the general government budget and risk-related premiums are not used, risk analysis and incentives for hazard control tend to be weak. At the same time, the financial liability of the government, or government enterprises, to its citizens for damages caused by the government itself, for instance to their health and safety, tends to be limited and ill-defined under socialism. It is often impossible to bring public entities to court to insist on fulfillment of their obligations or to recover damages. In all, social insurance tends to be implicit, unreliable, and unenforceable under socialism because it is viewed as a transfer programme subject to change at the discretion of government and not as a binding obligation defined by public law rather than just administrative rules and practices.

In centrally directed socialist economies, many prices are administered by the government, many goods are rationed or allocated outside markets, many financial instruments and services are unavailable, and the money and banking system is suited mostly to extract savings to finance the state apparatus and state industry. Government-owned infrastructure is rarely specifically insured against the normal range of insurable risks nor is there much incentive to insure the industrial property or product liability of government enterprises. The funding of such enterprises does not depend on the maintenance of insurance, and what damages arise tend to be borne in centrally administered budgets. As a result, risk analysis and risk management, even in such areas as occupational health and safety and workers' compensation, tend to be severely underdeveloped and haphazard. 
Although, by the beginning of the past decade, a number of CEE countries had already moved away from this extreme to a more mixed system incorporating private ownership and markets and somewhat improved legal security, the transformation of financial services to market standards tended to lag far behind that of other production and distribution sectors. Among the reasons were that government insurance monopolies, chronic loss-makers sustained on subsidies, were politically and financially difficult to privatize. ${ }^{2}$ A case study for Hungary that points to a number of unpleasant surprises encountered in the development of private motor vehicle insurance is given in Table 1.

Some of the difficulties encountered in the transition from mandatory noncontractual motor vehicle liability insurance provided by a state monopoly to contractual insurance provided competitively and with foreign participation remain of more than historical interest. Until the transition is completed in EU-member countries farthest to the East and in CIS countries, both insurance coverage and experience with changed behavioural incentives resulting from increased coverage will remain severely incomplete. For instance, the Financial Market Authority of Slovakia in 2001 still described the insurance relationship as arising automatically regardless of the will of the person owning or operating a vehicle: "There is no insurance contract involved; the vehicle is deemed insured [by the government] upon commencement of its operation [for all damages inflicted on third parties]. This form of insurance covers neither damages to the insured person's own motor vehicle, nor damages incurred by the owner, operator, or [passengers] of this vehicle."”

Hence, transitions made by frontrunners like Hungary more than a decade ago were still waiting to be completed in other CEE countries and have not even begun in earnest in most of the CIS countries.

Although the coverage of non-life insurance was incomplete, provisions needed to be made for insuring the value of some loan collateral, mostly property, and certain contingent liabilities even under late-stage socialism. As a result, non-life had been far less repressed than life insurance. There was, in fact, very little of the latter under socialism particularly if the life insurance had a strong savings component. ${ }^{4}$ In either

\footnotetext{
${ }^{2}$ Privatizations have, on occasion, even been suspended or reversed. PZU, Poland's former insurance monopoly, is a case in point. For details see $\operatorname{OECD}(2001,87)$ and EIU $(2003,15)$. A large presence of government in the contractual insurance market can distort and undercut private competition not only on account of the government subsidizing and otherwise favouring its own insurance business. Certain sharing (give-up) and local reinsurance requirements, which act like a tax on foreign insurers, also in effect require a transfer of income to the government insurance or reinsurance monopoly, or to other local companies that it controls. The investment policies imposed on such companies, in turn, may imply a reverse transfer, back to the government, if these companies invest almost exclusively in low-yielding Treasury securities.

${ }^{3}$ http://www.uft.sk/en/insurance/en/koncepcia.htm, p. 11 of 14, accessed 01/14/2005.

${ }^{4}$ In Poland, as in other CEE countries, revenues from non-life premiums were still about twice as large as from life premiums in 2000 . By contrast, by 2000 , life premiums were 50 per cent greater than non-life premiums in the EU. In Poland, non-life premiums were equal to 1.91 per cent of GDP while the corresponding insurance penetration ratio for the EU-15 was 3.25 per cent. For life insurance premiums, the corresponding percentages were 0.98 compared with 5.97 per cent. This indicated that the insurance penetration rate in Poland was 16 per cent of the EU-15 level for life insurance but 59 per cent for non-life insurance. See OECD (2002a, 26-27, 32-33).
} 
Table 1 Hungary's Automobile Insurance: The Pains of exiting from government control

\title{
Interview Report with Dr. Klaus Junker, Executive Vice President and Head of Central \& East European Markets, Growth Markets Division, Allianz Group
}

\author{
at Munich, Germany, 11 March 2004
}

In 1989, some Hungarian politicians, anticipating the demise of state socialism, approached trusted contacts at Allianz, inviting the company to assume the motor vehicle insurance monopoly of the state. These contacts refused the offer of a monopoly and helped create the legal framework for establishing competitive private insurance operations instead. Still, because Allianz was the first company to work through these matters with the Hungarian government and its financial experts in the transition, an entrepreneurial group within Allianz agreed to transform the former insurance monopoly into an Allianz subsidiary. That subsidiary would charge a premium for services that had formerly been paid for by other, less visible and less differentiated means. Paying premiums for coverage came as a rude shock to drivers, many of them state functionaries, who previously were automatically enrolled in a state insurance monopoly that dealt with collision and liability claims by means of general state subsidies, allegedly financed by the gasoline tax. Hence, car insurance had appeared free to drivers, at least free of direct financial cost.

This perception explains the intense resistance, including taxi-driver strikes that arose when Allianz proposed to charge a premium that would cover the expected cost of the insurance coverage provided. Those expectations were based on the assumption that drivers would continue to drive defensively and lavish care on the automobiles they had acquired, often after long waits, as they had under socialism. Another implicit assumption was that the police, much in evidence under the old regime, would continue to keep order and keep down the rate of theft. Two things then occurred that led to massive insurance losses:

(a) Eager to come to an agreement and to get going in a Comecon country, the company yielded to government pressure and scaled its introductory premiums down to somewhat less than expected cost. (b) Estimates of insurance claims proved far too low.

The reason was that the opening of Hungary's border with Austria created a whole new set of opportunities and incentives, all of which tended to raise insurance claims. Specifically, as modern used cars became available through Austria, the existing automobile stock in Hungary quickly lost value by comparison with the Western imports. However, the obsolete stock remaining insured for collision and theft at a hypothetical replacement cost was not based on current used-car prices for Trabants and other Eastern-bloc vehicles. Hence, these cars became worth more wrecked or stolen than well maintained by their owners and kept on the road. Correspondingly, theft was encouraged particularly across the Ukrainian border,

undermaintenance and reckless driving became rampant, and wrecks and crashes multiplied. After a year or two, it looked like the first private venture into Hungarian insurance in over 40 years would fail miserably. To avert such a disastrous outcome and to keep adverse signals from potential foreign investors, the Hungarian government, recognizing that its attempts to depress the insurance premiums charged by the company to unsustainably low levels had played a part in the debacle, decided to keep the Allianz subsidiary afloat through a government subsidy not unlike those given before, but for the last time. Car insurance premiums subsequently were deregulated and Allianz built a diversified and eventually highly profitable business in Hungary using car insurance as the lead to marketing other insurance products to clients. The company's market share in Hungary now is 28 per cent, compared with 17 per cent of Allianz Group in its home market, Germany. Its market share in motor lines in Hungary is still about 50 per cent.

case, what contractual insurance, voluntary or compulsory, there was outside the implicit "social insurance" system usually was provided by a single government monopoly. Compulsory insurance participation or other compulsory insurance features, by precluding adverse selection based on private information by the insured, may enhance private insurability in some situations. On the other hand, the element of premium and benefit regulation that tends to accompany public insurance mandates may become so large that insurance efficiency objectives, of correctly pricing identifiably different classes of risks, recede behind redistributional and imposed 
solidarity objectives. Private provision of specialized insurance services, particularly in relation to international trade, was tolerated in some CEE countries at the fringes.

Privatization of socialized industry and service provision has created a large potential demand for private insurance. Even where government ownership, for instance, of public utilities, transportation and communication systems, and other types of infrastructure was maintained, facilities might now be built and operated by private suppliers to government order. These private providers are liable to the contracting government agency, as to any other client, for contract fulfilment. Privatization and rapid redevelopment thus have supported the extension of new forms of finance and insurance. A good example is provided by Swiss $\mathrm{Re}^{5}$ with regard to Delay in Start-Up (DSU) insurance coverage concerned with large infrastructure projects previously funded by the government and now increasingly dependent on private financing:

The global privatization trend in recent years has had a profound impact on the situation of the various parties involved ... Principals now often collateralise loans with project assets and repay them purely on the basis of projected earnings. The revenue-generating capability of a project has thus become a critical financing factor and, accordingly, stringent conditions regarding delays in scheduled project completion have been added to contracts between financiers and principals, and particularly to those between principals and contractors. The principal's financing risk involves, for example, revenue loss, accepted amounts payable to customers or suppliers, cost overruns or consultant fees. The contractor, on the other hand, is faced with risks such as additional cost of construction, material and labour... This has prompted a sharp rise in demand for delay in start-up (DSU) cover, which is also known as advance loss of profit (ALOP) insurance. ${ }^{6}$

Components of DSU, such as Marine Cargo Delay in Startup insurance, can also be combined with a number of other specific employment, construction, engineering, and property-risk types of coverage to provide comprehensive Build-Operate-Transfer (BOT) insurance for privately financed infrastructure projects, as Allianz explains in describing its current Products \& Services.

Of course, the effects of privatization on stimulating demand for various types of insurance do not end there. For instance, for diverse private producers of the same or similar goods to find a ready market, their products need to be certified as conforming to quality standards set by the International Standards Organization (ISO) or the European Committee for Standardization known by its French acronym as CEN. In the EU, "products which have successfully undergone the appropriate assessment procedures are then affixed the CE marking, which grants free circulation in all Member States [avoiding technical barriers to trade], but also implies that the producer accepts full liability for the product". ${ }^{7}$ To cover the risk of incurring

\footnotetext{
${ }^{5}$ Swiss Re $(2003,12)$

${ }^{6}$ Swiss Re $(2003,5-6)$

${ }^{7}$ OECD $(2002 b, 20)$.
} 
unusually high costs of the implied warranty would therefore require some form of "excess" product liability insurance. This is not the kind of liability that a socialist government and production system would normally recognize, at least not in regard to its own citizens.

\section{Foreign entry}

\section{Foreign establishment with investment of insurance reserves in the host country}

When foreign companies were allowed to establish in formerly socialist countries or to take over some of the insurance operations that were being privatized, there often was a dearth of investable assets in those countries. This hampered foreign participation because insurance regulation required that claims against local parties had to be set against the local insurance liabilities assumed, and foreign insurers did not find it commercially feasible to include government debt importantly among those local claims. ${ }^{8}$ A detailed analysis drawing on the experience, examples, and proposals of Dr. Junker follows.

Countries usually require that (almost) all insurance assets that represent reserves against policies written for their residents be invested locally. There is a logic for this requirement, say, in the case of savings-intensive life insurance and pension products when the insured expects to consume in the home country and would like to earn real rates of return in relation to her prospective consumption basket without bearing the risk of lasting changes in real exchange rates. In other cases, such as when the insurance covers the loss of machinery that has to be imported, defining insured values in foreign currency and holding credible foreign-currency instruments as an insurance reserve against such liabilities would be wiser even if suitable domesticcurrency instruments were available. In general, however, CEE countries have severely limited the percentage of reserve assets that may be invested in claims on foreign obligors.

If almost all the insurance business that is written in a country has to be reserved domestically, there is a problem if the domestic market is not yet judged to be investable for private companies. The reasons for such a failure may be lack of depth, transparency, and liquidity and a lack of legal security or of predictable application of existing rules and laws, including those relating to bankruptcy and seizure of collateral. The Russian market, for instance, did not pass the test of investability based on these criteria until 2000 at the earliest, and its reputation is still shaky. Hence, if the bulk of insurance written in a country must be reserved domestically, but the domestic market is not investable for private companies, their participation in that market will be severely limited. ${ }^{9}$ Instead, what contractual non-life insurance there is will be

\footnotetext{
${ }^{8}$ Domestic insurers, often technically bankrupt, were more likely to lend to government in return for regulatory forbearance.

${ }^{9}$ In the years of hyperinflation in Bulgaria (1990-1995), Bulgarian real estate assets were acquired outright as significant investments by Bulgaria Insurance Co. to serve as domestic reserves against the insurance written in Bulgaria. The normally unacceptable risks associated with attempts to compensate for a lack of domestic investability in this way are obvious, although the company came away with large profits from
} 
provided by public insurance monopolies, often with subsidies from the state budget, and contractual life insurance generally would not be offered at all. If there is financial repression and appreciable inflation in a country as well, real interest rates for savers could well be negative even when they invest in interest-bearing savings deposits rather than domestic currency. Under these conditions, ordinary savers as well as those who need to hide illicit gains would be inclined to hoard hard-currency assets either in the form of currency (mattress saving) or, in the case of those who are internationally well connected, in the form of foreign financial or real estate assets.

This largely invisible capital export (-) implies a corresponding leakage of resources out of the country without visible recompense; its counterpart could be a higher $(+)$ current-account balance. If the private capital flight $(-)$ is financed instead by increased official external borrowing $(+)$, higher sovereign debt is the visible counterpart. It implies increased future claims on a country's output. Freshly laundered savings of hard-currency assets, and their nominal yield do not tend to return to the country that generated these savings. Instead, they tend to be expatriated permanently.

\section{Transitional foreign investment of funds serving domestic insurance purposes?}

Could something more constructive be done at least for the mass of people who accumulate dollar or euro bills and thereby engage in a capital export that is forced on them for lack of domestic-currency instruments suitable for life-insurance and old-age income security? Dr. Junker's proposed initiative here was to allow supervised foreign investment funds to be offered in countries like Russia to lure the dollar and euro bills out from under the mattress and into investments with a positive real rate of return. The next step would be gradually to diversify the funds' investments into domestic currency instruments as the capital market in the clients' country matures and becomes investable. This would reverse part of the original capital export. These diversified reserve assets then would be available to honour claims whether arising from premature death, annuities to protect against outliving one's own assets, or straight pensions with survivor benefits, among others.

A final step would be to give the country the benefit of sound international money through accession to European Monetary Union (EMU). In that event, the assets of the country in question would become eligible for holding by a much wider range of financial institutions and investors of other member countries. Conversely, assets of the other member countries would be eligible for investment by the country in question. As a result, net capital exports associated with provision of old-age security could fall even to zero without losing the benefits of international diversification because such diversification would be mutual. Indeed, financially highly developed countries are characterized by gross international capital flows that are many times larger than the net flows.

this unconventional investment concentration in real estate. In 1998, the company became a subsidiary of Allianz Group. 


\section{Limitations of cross-border provision of insurance services}

In transnational and multinational corporations, relying on insures and re-insurers from several countries may appear routine. Indeed, those who made foreign direct investments in CEE countries often want their insurers to go with them and to pay settlements at home in a major currency. This creates a demand for some cross-border insurance business that may require special permission from local insurance supervisors and regulatory authorities.

Except in regard to transnational and multinational corporations, however, sales of insurance products are advanced by local brand names that clients trust because they are aware of a record of fair treatment accorded to those (parents, business associates) whom they know. Cross-border provision of insurance services, even when permitted by local law, thus may be difficult to market. SMEs and retail customers are looking for "trusted names" that act like local companies and have become household words. To reach such customers, insurance companies prefer foreign establishment and local branding. Even after established domestic companies have been taken over by foreign companies, they typically first retain their local names, and rebrand, in steps, walking clients over to the company's global brand identity only gradually. Colonia to AXAColonia to $\mathrm{AXA}^{10}$ is an example of such name conversion in stages applied to an old, originally German, company and its global subsidiaries. Allianz followed this practice in Hungary changing the brand 10 years after acquisition from Hungaria Biztosito to Allianz Hungaria Biztositó. Eventually, conditions may be ripe for indicating directly that the local subsidiary is backed by a long-established international insurance company.

Although "national tradition and trust" may be the main reason for home bias in insurance, such a bias could have been rational in the past because national insurance regulators and bankruptcy courts may have been able to favour, that is, prioritize, local policyholders' claims in the event of an insurance company's insolvency and liquidation. Hence, independently capitalized local subsidiaries of foreign companies would be more acceptable as insurance underwriters than local branches of foreign companies or cross-border providers.

While cross-border provision of insurance services is still rare in the segment of the market below the MNC level in CEE countries, this may change now that most of these countries have joined the EU. Swiss Re Sigma ${ }^{11}$ details the steps that were taken during the period of EU accession negotiations, which started in March 1998, to comply with the EU's three insurance directives relating to (1) freedom of establishment (for foreign companies), (2) freedom to provide services (without

\footnotetext{
${ }^{10}$ Colonia was a diversified insurance company with a long tradition, which began in the fire insurance business in Cologne already in 1839. Many of its subsidiaries thus kept Colonia as part of the new company name when it was taken over by AXA in 1996. However, Colonia Insurance Company New York had its name changed to AXA Global Risks US Insurance Co. right away (effective 12/08/1997) presumably because the AXA name was thought to trump the Colonia name in the U.S. market. In Germany, Colonia Versicherungs AG now has completed the name-change cycle, via AXA Colonia Konzern AG in 1996, to AXA Konzern AG currently.

11 Swiss Re Sigma (2001, 21, 22).
} 
restriction by scope or mode, such as cross-border), and (3) abolition of state monopolies and government price controls together with the adoption of regulations for competition policy and prudential oversight. Adoption of strict solvency and minimum capital standards and establishment of an independent supervisory agency were part of meeting the third requirement. By the end of 2000, Poland had met all these EU insurance-industry entry criteria. ${ }^{12}$ Once it is anticipated that the EUaccession countries will also join EMU by a certain date, the investment portfolios of insurance companies will become much more diversified, and hence similar, across the euro area. With an EU insurance directive already prohibiting discrimination against policyholders from other member countries in the event of liquidation, ${ }^{13}$ and with reserve investment portfolios similar, much of the rational basis for home-country bias in the choice of insurer would disappear.

\section{Insurability and insurance opportunities under CEE-country conditions}

Volatile currencies and national markets that are not investable, businesses with illdefined business risk exposures, and loss-making businesses all jeopardize insurance. For instance, it is not safe to require insurers to offer a guaranteed fixed minimum nominal rate of return on life products in a soft currency when that currency may turn hard one day or disappear entirely. Having to guarantee 12 per cent in forint on life policies written in Hungary in the second half of the 1990s was a reckless imposition since such a commitment would become unaffordable once Hungary moved towards low inflation rates. By contrast, Germany's guaranteed minimum rate was down to 2.75 per cent in 2004 . This is a level currently compatible with approximate stability of its price level which is defined, (as for the euro area as a whole), as average annual inflation rates no greater than 2 per cent per annum. Formal adoption of the euro through membership in EMU will create much greater intertemporal stability of the purchasing power of money for CEE countries. It will also broaden the regional scope of investments that can be used for insurance reserves without incurring direct or indirect (i.e., counterparty) currency risk.

Another limit to insurance comes from ill-defined, potentially massive, risk exposure. For example, the product liability of pharmaceutical companies producing knock-offs in CEE countries so far has proved uninsurable. The reason is that weak supervision and enforcement regarding product purity, consistency, stability, and safety have led to conditions that defeat actuarial calculations and insurance. By the same token, businesses that see a string of losses before them and little hope of recovery are always susceptible to undermaintenance and insurance fraud through intentional destruction or the setting up of accidents waiting to happen. To the extent

\footnotetext{
${ }^{12}$ Swiss Re Sigma (2001, 22).

${ }^{13}$ Article 16.2 of the Insurance Directive 2001/17/EC on reorganizing and winding up of insurance undertakings states: "The claims of all creditors who have their normal place of residence, domicile or head office in a Member State other that the home Member State ... shall be treated in the same way and accorded the same ranking as claims of an equivalent nature lodgeable by creditors who have their normal place of residence, domicile or head office in the home Member State".
} 
transition countries find themselves saddled with large amounts of obsolete fixed capital assets, inventories, and facilities, almost by definition insurance thus is inhibited by moral hazard considerations.

On the other hand, Dr. Junker also pointed out a condition more favourable to insurance in the CEE countries than in countries operating with high degrees of value agglomeration in crowded places such as Lower Manhattan or Hong Kong Island. High value and network concentration in a small space magnifies the losses resulting from physical destruction befalling any of a large number of occupants and parties connected to that space. In CEE countries, however, land-using technologies that have led to considerable physical dispersal of assets in autarchic production locations have reduced adverse spillover and mutual exposure. Furthermore, as the vertically integrated industrial combines typical of socialist industry are unbundled in the process of privatization, independent ownership results from separate sale of their viable parts to new owners. This creates new insurance needs as the spin-offs are no longer implicitly and collectively insured as part of state enterprise. Industrial customers may value the spin-offs' acquiring adequate insurance cover to prevent or compensate for costly interruptions in supply or other risks that could endanger longterm business relationships. Indeed, being able to do business at arm's length, without the need for personal contacts and investments in friendships and complicity, is one of the benefits of insurance. These benefits may be particularly pronounced in CEE countries where inefficient bypass strategies, around formal channels, had been encouraged by a failing system.

\section{Insurability in emerging markets generally, and reliability of insurance}

As detailed methodically by Courbage and Liedtke, ${ }^{14}$ risks that cannot credibly be insured/reinsured by even the largest and best managed companies with the available forecast and risk assessment and abatement technologies are outside the limits in which private insurance can operate. Thus, insurability may fail in principle if the maximum potential loss, while presumably extremely rare or unprecedented, is also very large on a global scale on account of geographic or functional spillovers or other sources of positive loss correlations. Other limits to insurability arise from inability to control moral hazard in certain areas where there is a demand for insurance. There are also emerging risks that are due to changes in the legal, technological, physical, political, or human environment where insurability is impeded, at least for a time-tolearn, for lack of actuarial norms needed to design and price the appropriate policies. For example, legal innovations with as yet highly uncertain applications and financial consequences may occur in liability legislation relating to the prevention of terrorism, environmental impacts, and genetic engineering. At the same time, physical changes, such as adverse climatologic, biological, and epidemiological developments, including the outbreak of new diseases such as SARS, may pose hazards that are initially difficult to quantify in probability and cost dimensions. Policies that cover "all risks"

\footnotetext{
${ }^{14}$ Courbage and Liedtke (2002).
} 
except those specifically excluded may not be credible when and where the emergence of previously unknown risk factors is high.

In practice, insurability is determined not just by the characteristics of risks but also by the limited management capabilities and capacity of potential insurers. Thus, industry capability, including the capital adequacy, risk rating and prospective solvency of individual insurers, and the reliability of their reinsurance arrangements, also determines the effective degree of insurance. For example, currency and financial crises are a recurring phenomenon. Many of the losses they cause may be privately insurable, in principle, in spite of the possibility of contagion among emerging-market countries. Nevertheless, insurance cover may fail just when it is most needed. One of the most vivid recent examples combining insurance default with legal plunder comes from Argentina early in 2002. The protracted economic and financial crisis that had deepened throughout 2001 had weakened both life- and non-life insurance by the following:

- Sharply reducing the domestic-currency value and liquidity of their assets through general deflation of local debt and equity claims and through specific company and (provincial) government defaults or bankruptcies in advance of the abandonment of the currency-board parity.

- Exposing currency mismatches between assets and liabilities on account of widespread liability dollarization during the currency crisis as both life and property policies (such as policies securing U.S. dollar mortgages or other U.S. dollar loans) often were denominated in U.S. dollars.

- Precipitating large-scale withdrawals of life-insurance savings both to shore up living standards during the economic and financial crisis and because of concerns about the solvency of insurers.

- Worsening loss experience through undermaintenance of plant and equipment and through other factors in the wake of the crisis: in Argentina, one-third more cars were stolen in 2002 than in 2001.

- Reduced premium inflow as households in particular ceased to purchase insurance or switched from high-premium savings-type policies to low-premium pureprotection products as their living standards plummeted.

Swiss Re Sigma goes on to explain how the government orchestrated a confiscatory write-down of insurance claims, along with the dollar claims of depositors in Argentine banks, to shore up the insurance sector:

In Argentina, nearly all individual life policies were denominated in U.S. dollars. Contracts with a savings component were mostly cancelled as soon as the 1:1 parity of the local currency to the U.S. dollar was abandoned. They were converted into peso contracts, with savings being converted at a rate much lower than the actual exchange rate. ${ }^{15}$

Insurers' dollar liabilities, like the dollar bank deposits, were converted at a rate of 1.40 pesos to one U.S. dollar, additionally adjusted for inflation. In fact, however, at

\footnotetext{
${ }^{15}$ Swiss Re Sigma (2003c, 13).
} 
the close of Friday, 1 February 2002, just before the new measures were announced that were to go into effect on 4 February, the peso was quoted at 2.0251 to the dollar, implying an instant confiscation or write-down of the dollar claims by 31 per cent. Although the peso overdepreciated to as much as 3.95 on 26 June 2002, it steadied at about 3 pesos to the dollar in 2003-2004. This rate still implied a loss of over 50 per cent for those who had planned to keep their life policies in U.S. dollars. Although some foreign life insurers operating in Argentina may have given terms of conversion better than 1.40 pesos per dollar, the popular assumption that all such insurers would choose to honour their obligations fully even if local law allowed them to do otherwise proved false. In Argentina, foreign insurers had a market share of almost 50 per cent in non-life and over 70 per cent in life insurance at the start of the latest crisis. ${ }^{16}$

Although accession countries such as Poland are at a level of development comparable to that of (re)emerging-market countries such as Argentina, they are not likely to be exposed to similarly severe currency, financial, or fiscal crises. The reason is that first EU accession in May 2004 and then the prospect of joining EMU in coming years have provided a firm compass for their institutional and economic development. These membership goals have guided their policy conduct and anchored investor expectations. Nevertheless, financial strength ratings, ${ }^{17}$ designed to rate insurers' ability to pay policyholder claims and obligations fully and promptly, and stress testing ${ }^{18}$ of insurance companies within an established supervisory framework is less advanced in the accession countries than in the core countries of the EU that are large exporters of insurance services. International diversification of the portfolios of insurance companies and subsidiaries operating in accession countries may still be severely restricted. ${ }^{19}$ Hence, insurance companies, and thus their policyholders, may not be fully prepared for, and thus not reliably protected from, the several sources of financial distress associated with macroeconomic event and policy risk.

\footnotetext{
${ }^{16}$ Swiss Re Sigma (2003c, 25).

${ }^{17}$ Of the 140 rating firms in the world, just four are said to have widespread credibility and employ more than 100 analysts: A.M. Best, Fitch Ratings, Moody's Investors Service, and Standard \& Poor's. A.M. Best focuses exclusively on the insurance sector. For further details of the rating process and a review of its problems and achievements, see Swiss Re Sigma (2003a). Maurer (2004, 120) notes that Kahneman and Tversky (1979) and Wakker et al. (1997) used the term probabilistic insurance to point out that most insurance is, in fact, only pseudo-certain, being marketed without mention of its default risk. In the U.S., 1 or more per cent of all non-life companies became insolvent each year from 1984 to 1993, and both the U.K. and France had some similarly high rates of insolvency in 1992-1994, while Germany had no insolvencies 1980-1999. See Swiss Re Sigma (2000, 5). According to Swiss Re Sigma (2003b, 3), the likelihood of bankruptcy in the reinsurance sector is extremely slight.

18 Macroeconomic Stress Tests, for instance for the external debt ratio, are now routinely included in IMF Country Reports (e.g., IMF (2003, 31); see also IMF (2002); Swiss Re Sigma (2003c)). Industry stress tests, by contrast, must ultimately get down to the company level to determine the frequency and severity of liquidity and solvency problems that may be encountered.

19 Since March 1997, insurers have been able to invest up to 5 per cent of their funds (in securities rated no lower than BBB) in OECD countries and in other countries with which Poland has signed treaties supporting investment (EIU, 2003, 16).
} 
Conversely, extravagant and/or extraterritorial liability legislation may create exposures for business that are essentially uninsurable due to lack of conditional predictability of the settlement sum. More generally, knowledge that a party carries insurance with "deep pockets" may encourage legal action against such party for awards well in excess of actual damages. Not only juries who tend to identify with the victim but also attorneys and judges, particularly elected judges as in the United States, may be inclined to favour (classes of) "small" clients at the expense of "large" corporations. Such a populist hazard or juridical bias could well confront private insurers in countries that have emerged from socialism. Hence, both existing insurance policies that their providers can or do not fully honour in certain situations, and coverage that they are unable to provide, or must cap severely for lack of a predictable relation between damage and award, present problems of insurance reliability and completeness.

\section{Using banking networks for marketing insurance}

In emerging-market countries, particularly those that emerged from socialism, the client base of banks and savings institutions often reached much farther down the socioeconomic ladder than the client base of what private insurance companies there were. Banks may have had a fairly dense network of branches covering the country. Furthermore, telemarketing and Internet sales of both bank and insurance products were still rare.

Under these conditions, foreign insurers desiring to enter an emerging-market country that had opened up may have a strong incentive to use existing bank networks to jumpstart their business even though the provision of some specialized insurance services outside banks may prove more efficient in the long run. Life insurance products with a large savings component and pension products obviously are compatible with savings products of banks, thereby extending their menu. In the nonlife area, various types of property and accident insurance are crucial to managing the risks associated with credit that is based on the current market value of the security properties or on the cash flow that they are expected to generate. Thus, the existence of insurance can enhance access to credit by protecting the collateral value of fixed assets and reducing the risk of extended business interruption and bankruptcy after a major accident. Yet non-life types of policies that require detailed risk analysis and management and elaborate claims service in each individual case depend on an insurance expertise not normally found in traditional banks. These types of products cannot be sold over the counter by quickly retrained personnel but require detailed involvement by experienced insurance agents, brokers, or underwriters. Hence, merely using existing foreign-bank networks and their staffs is not likely to generate either deep insurance-product penetration or a level of customer satisfaction that protects the insurer's business reputation and image.

The solution sought by Allianz in the CEE countries has been to gain outright control of CEE banking networks in conjunction with a foreign bank partner. Allianz thus has used minority partnerships with UniCredito Italiano to acquire banks in CEE countries such as Poland's Grupa Pekao, SA, and Croatia's Zagrebacka Banka, which 
are the two countries' largest banks. The end result down the road could be more in the direction of an insurance company also engaged in banking activities (assurebanking) than a bank also engaged in insurance (bancassurance).

Dr. Junker elaborated on a case where marketing newly mixed and matched bancassurance products in the life area was not easy even though a clearly superior composite substitute for a traditional single-line insurance product could be offered. The goal was merely to separate bankable-savings and pure-risk-insurance features to generate tax savings for investment in value-accumulating life insurance. Clients had difficulty understanding that decomposing a traditional life insurance product into its saving and pure-insurance components did not change any of the characteristics of the combination compared with the traditional, bundled life insurance product.

The problem arose when accumulating life insurance premiums were subjected to a VAT of 5 per cent in the mid-1990s in Bulgaria. The solution proposed by Dr. Junker was first to purchase a small bank there and convert it to a Special Purpose Vehicle (SPV). This SPV would only take deposits under long-term savings plans with withdrawal penalties and invest the proceeds long term, if possible, while having no other dealings with the public. A charge for non-accumulating term-life insurance would be added to the funds used for the savings deposit, and only this small component of the total life premium previously paid now would be subject to the VAT. Nevertheless, CEE customers balked at purchasing the more cost-effective equivalent made up of a bank product and a pure-insurance product that would have passed on the tax savings. They preferred to stick with the traditional, familiar accumulating life insurance instrument whose premiums were subject to the VAT in their entirety. Today, the VAT on life premiums is down to 2 per cent and there are plans to abolish it altogether this year.

Marketing combinations of insurance and bank products in-house through bancassurance or through joint-marketing ventures has yet to prove very successful in the CEE countries. There banks still tend to give very little "credit" for insurance. Combination products are difficult to market on account of their perceived complexity. To intensify marketing efforts, cross share-holding between banks and insurance companies increasingly is used to mimic the management incentives of joint ownership where each side benefits directly from the other's success. These attempts too have not proved their worth yet in Central and Eastern Europe. Caution is in order since cross-gearing can lead to endogenous propagation of insolvency across different financial sectors as it had done in Japan in recent years.

\section{Conclusion}

Perhaps one of the most pointed lessons to be derived from the transition from highly incomplete non-market to market insurance in the CEE countries is that the transition itself will give rise to unexpected risks. A major change shifting the boundaries between public and private insurance schemes modifies the rights and incentives of those seeking insurance in relation to insurance providers.

For instance, automobile owners/operators who cannot insure themselves or their vehicles for accidents they cause may have every incentive to be extra careful 
particularly if their cars remain valuable and hard to replace with something better. This extra care then also tends to keep down the third-party liability claims arising from accidents that are insured even though no underwriting, premiums, or experience ratings are used to control risks individually. Moving from such a non-contractual public to a contractual private system that includes coverage for damages suffered by the insured's vehicle or person and even for loss through theft can change risk and claims behaviour dramatically. Being locked into insurance pricing that subsumes past experience when insurance regimes change thus can turn out to be a recipe for disaster.

Changes in public rationing, in types and extent of coverage, and in regulated pricing and cross-subsidization of public insurance, and its displacement or supplementation by private insurance, are actively debated in several important fields, such as health and social security, in a number of countries. The experience with major and sudden insurance-system change in the CEE countries cautions against underestimating the extent of uncertainty about the insurance prices and values to be associated with major systems substitutions such as those currently considered in several of the most advanced countries. Modelling or simulating the many simultaneous and interdependent aspects of system change, including political and private-incentive change, may at least give a sense of the wide range of possible outcomes that define the extent of "transition risk."

Transition from socialism also means that the sector most repressed by the very nature of socialism - private finance and financial markets - can catch up only gradually with other sectors, such as heavy manufacturing, whose development has been stunted less. ${ }^{20}$ This uneven development could limit private insurability, for instance, as long as domestic financial markets are not fully or safely investable since claims on local obligors have had to be held as insurance reserves against local policies written by foreign and domestic insurers nonetheless.

Insurability is also limited from the side of clients in some CEE countries as they are not yet fully accustomed to seeking both life and non-life insurance services and understanding the range of private financial products offered. Hence, business models that may be quite successful in countries with financially more experienced clients may fail, at least initially, in transition countries. By the same token, one should not exaggerate the ability of low- and middle-income persons even in financially advanced countries like the United States to make well-advised choices regarding privatepension and health plans and their administration. In such areas where the choices of individuals may have major consequences for the well-being of entire families over decades, society cannot be indifferent to the careful training and advising required before consumer sovereignty can be exercised responsibly. For Dr. Junker as a strategist and man of character, successful marketing in this area would mean making an investment in customer good-will and business reputation by selling products whose buyer, years later in possession of all the facts, would have reason to be thankful. Will the various national governments currently pushing or blocking reform and restructuring programmes in the most advanced countries submit to the same test?

\footnotetext{
${ }^{20}$ see von Furstenberg (2004).
} 


\section{References}

Courbage, C. and Liedtke, P.M. (2002) 'On insurability and its limits', in P.M. Liedtke and C. Courbage (eds) Insurance and September 11 - One Year After, Geneva: The Geneva Association, pp. 227-234.

Economist Intelligence Unit (EIU) (2003) Country Finance: Poland, New York: EIU, July.

International Montary Fund (IMF) (2002) The design of the sovereign debt restructuring mechanism-further considerations, Prepared by the Legal and Policy Development and Review Departments, November 27.

International Monetary Fund (IMF) (2003) Republic of Poland, staff report for the 2003 Article IV consultation, IMF Country Report No. 03/187, Washington, DC, June.

Kahneman, D. and Tversky, A. (1979) 'Prospect theory: An analysis of decisions under risk', Econometrica 47: 263-291.

Maurer, R. (2004) 'Institutional investors in Germany: Insurance companies and investment funds', in J.P. Krahnen and R.H. Schmidt (eds) The German Financial System, Oxford: Oxford University Press, pp. 106-138.

OECD (2001) OECD Economic Surveys: Poland (May), Paris: OECD.

OECD (2002a) Insurance Statistics Yearbook, 1993-2000, Paris: OECD.

OECD (2002b) Regulatory Reform in Poland: From Transition to New Regulatory Challenges, Paris: OECD. Swiss Re (2003) Delay in Start-Up Insurance, Zurich: Swiss Reinsurance Company.

Swiss Re Sigma (2000) Solvency of non-life insurers: Balancing security and profitability expectations, No. 1/ 2000, Swiss Reinsurance Company, Economic Research and Consulting, Zurich (applies equally to next four citations).

Swiss Re Sigma (2001) Insurance in Central and Eastern Europe, No. 1/2001.

Swiss Re Sigma (2003a) Insurance company ratings, No. 4/2003.

Swiss Re Sigma (2003b) Reinsurance - a systemic risk? No. 5/2003.

Swiss Re Sigma (2003c) Emerging insurance markets: Lessons learned from financial crises, No. 7/2003.

von Furstenberg, G.M. (2004) 'The contribution of rapid financial development to asymmetric growth of manufacturing industries: Common claims vs. evidence for Poland', Journal of Economic Asymmetries 1(2): 87-120.

von Furstenberg, G.M. and Ulan, M.K. (1998) Learning from the World's Best Central Bankers: Principles and Policies for Subduing Inflation, Boston: Kluwer Academic Publishers.

Wakker, P.P., Thaler, R.H. and Tversky, A. (1997) 'Probabilistic insurance', Journal of Risk and Uncertainty 15: 7-28. 